J. Clin. Chem. Clin. Biochem.

Vol. 20, 1982, pp. 113-117

\title{
Porphyrinogens in Urine in Various Types of Porphyrias
}

\author{
By P. Martásek, M. Jirsa and V. Kordą
}

Research Laboratory for Blood and Liver Diseases, 1 st Medical Department, Faculty of General Medicine, Charles University, Prague, Czechoslovakia

(Received March 9/October 29, 1981)

Summary: Porphyrinogens were determined in very fresh, diluted morning urine in two types of hepatic porphyria, using a simple and very quick spectrophotometric method. It was shown that acidification by itself is insufficient for the complete conversion of colourless porphyrinogens into porphyrins in photometric determination of porphyrins in diluted urine. A correlation was shown between percentual content of porphyrinogens and the sum of pentacarboxyporphyrin and coproporphyrin. A difference was found between the excretion of porphyrinogens in morning fresh urine in porphyria cutanea tarda (average porphyrinogen fraction $22.5 \%$, SD $10.3 \%$ of total porphyrins) and in acute intermittent porphyria (average porphyrinogen fraction $77.1 \%, \mathrm{SD} 9.3 \%$ of total porphyrins). The method is at the same time suitable for the detection of urobilinoids in urine. Oxidation of the urine in acute intermittent porphyria is recommended before adsorption on talc and subsequent thin-layer chromatography, because porphyrinogens are not adsorbed on talc.

\section{Porphyrinogene im Urin bei verschiedenen Typen von Porphyrie}

Zusammenfassung: Es wurden Porphyrinogene in sehr frischem Morgen-Urin bei zwei Typen von hepatischer Porphyria bestimmt und zwar mit einer sehr schnellen spektrophotometrischen Methode im verdünnten Urin. Es wurde erwiesen, daß die Ansäuerung allein für eine vollständige Veränderung der Porphyrinogene in Porphyrine für die photometrische Bestimmung im verdünnten Urin nicht genügt. Eine gute Kơrrelation zwischen dem Gehalt der Summe des Pentacarboxyporphyrin + Koproporphyrin und der Porphyrinogene wurde gefunden. Wir haben einen Unterschied zwischen der Ausscheidung der Porphyrinogene im frischen Morgen-Urin bei Porphyria cutanea tarda und bei akuter intermittierender Porphyrie festgestellț. Der Anteil der Porphyrinogene bei Porphyria cutanea tarda war im Durchschnitt 22,5\%, SD $10,3 \%$ und bei akuter intermittierender Porphyrie 77,1\%, SD 9,3\% der Gesamtporphyrine. Die Methode ist auch für die Bestimmung der Urobilinoide im Urin geeignet. Es wird empfohlen, den Urin bei akuter intermittierender Porphyrie vor der Adsorption an Talk zu oxidieren und erst dann die DünnschichtChromatographie durchzuführen, weil die Porphyrinogene nicht an Talk adsorbiert werden.

\section{Introduction}

Porphyrinogens are colourless, reduced porphyrins without the characteristic Soret absorption maximum. Protoporphyrin IX originates in the organism by the enzymatic oxidation of protoporphyrinogen. The other porphyrins originate by non-enzymatic oxidation of their corresponding porphyrinogens (1). Fischer (2) described the isolation of coproporphyrinogen in the stool of his patient Petry. Watson et al. (3) showed that 25-66\% of coproporphyrin is present in the fresh urine of porphyric patients in the form of coproporphyrinogen. Holecek (4) has ascertained that $97 \%$ of coproporphyrin is excreted in the form of coproporphyrinogen during lead poisoning. Sano \& Rimington (5) have shown that coproporphyrinogen, and not coproporphyrin, is excreted by the kidneys.
Earlier determinations of porphyrinogens were based on extraction in various solvents, or on the different adsorption of porphyrinogens and porphyrins on calcium phosphate (6). It has been claimed that acidification of urine is sufficient for the quick conversion of porphyrinogens into porphyrins $(7,8)$. Schwartz et al. (9) used iodine as an oxidation agent; $\mathrm{H}_{2} \mathrm{O}_{2}(10,11)$ and light are also used. Recently chloranil was used (12) for the oxidation of porphyrinogens into porphyrins for fluorometric determination of total porphyrins and porphyrinogens in diluted urine (13).

Very little attention has been given to studies on the

i excretion of porphyrinogens in different types of porphyria (14). Most of the published work is concerned with porphyrinogens from the point of view of the most complete determination of total porphyrins, 
and not with the determination of porphyrinogens themselves. Our interest lay in the quantitative determination of porphyrinogens and its diagnostic importance and meaning.

\section{Materials and Methods}

\section{Reagents}

Oxidizing agent $-1 \mathrm{~g}$ of iodine, $2 \mathrm{~g}$ of $\mathrm{KI}, 300 \mathrm{ml}$ of distilled water (Solutio Lugol). $L$-Cysteine monohydrochloride (monohydrate) was obtained from N.B. Co., Cleveland, Ohio. Chloramine T was obtained from British Drug Houses Ltd. All other reagents were of analytical grade, obtained from Lachema Brno, $\mathrm{np}$. Pure uroporphyrin and coproporphyrin were prepared according to With (15) and the purity was checked by thinlayer chromatography of the methylesters.

\section{Subjects}

Urine was collected from 20 porphyric patients, 10 of which had clinical and biochemical symptoms of porphyria cutanea tarda, without cirrhosis hepatis, aged 51 to 64 (mean 54, SD 4.9 years). A liver biopsy was done on all patients in the course of hospitalization and a high content of porphyrins in liver tissue was found. The other 10 patients were diagnosed as having acute intermittent porphyria, aged 19 to 45 (mean 32.1, SD 7.3 years). The urine was taken from all patients by spontaneous miction and treated immediately (within a few seconds). The collection and treatment was always carried out at 7:00 a.m. (in order to respect the daily rhythm of the excretion of porphyrins).

Preparation of porphyrinogens

A mixture of porphyrinogens, uroporphyrinogen and coproporphyrinogen were prepared according to Falk (16), the amount of porphyrins determined by oxidation with Lugol solution being $79-92 \%$ (mean $86.1 \%$, SD $7.2 \%$ ).

Preparation of stercobilin

Stercobilin was isolated from stool according to Gray (17). Its purity was controlled by mass spectrometry and qualitative reactions. The mass spectrum was prepared by Dr. Ubik from the Institute of Organic Chemistry and Biochemistry of the Czechoslovakian Academy of Science, using the AEI MS-902.

Thin-layer chromatography and densitography of methyl esters of porphyrins

Thin-layer chromatography of methyl esters of porphyrins was carried out according to Doss (18) and the fluorometric scans were obtained using a Vitatron TLD 100 densitometer.

\section{Urine analysis procedure}

The urine was analyzed immediately after spontaneous miction. It was immediately bubbled through with $\mathrm{CO}_{2}$. First of all we determined the amount of total porphyrins in this urine without the use of an oxidizing agent: One ml of urine was diluted with $9 \mathrm{ml} \mathrm{H}_{2} \mathrm{SO}_{4}(1 \mathrm{~mol} / \mathrm{l})$ which had previously been bubbled through with $\mathrm{CO}_{2}$ (all procedures in dim red light). Cuvettes of light path 1.0 to $5.0 \mathrm{~cm}$ were used and the absorption of the prepared sample was measured in a recording spectrophotometer (Specord UV VIS, Carl Zeiss Jena) from 350 to $800 \mathrm{~nm}$. The amount of porphyrins was determined by the addition of a standard amount of porphyrins. We then oxidized the urine with iodine in a water solution of potassium iodide (Lugol solution): One ml of urine is mixed with $8.75 \mathrm{ml}$ of $\mathrm{H}_{2} \mathrm{SO}_{4}(1 \mathrm{~mol} / \mathrm{l})$ and $0.25 \mathrm{ml}$ of Lugol solution. One minute later a few granules of cysteine hydrochloride are added. We determined the content of porphyrinogens from the difference of the concentration before and after oxidation (fig. 1). We used $\mathrm{H}_{2} \mathrm{SO}_{4}(1 \mathrm{~mol} / \mathrm{l})$ because porphyrinogens are more stable in this acidification agent. One hundred fresh samples of urine from 20 porphyric patients were measured by this method. We used also chloranil $T$ and $\mathrm{H}_{2} \mathrm{O}_{2}$ as the oxidation agents and obtained variable results.

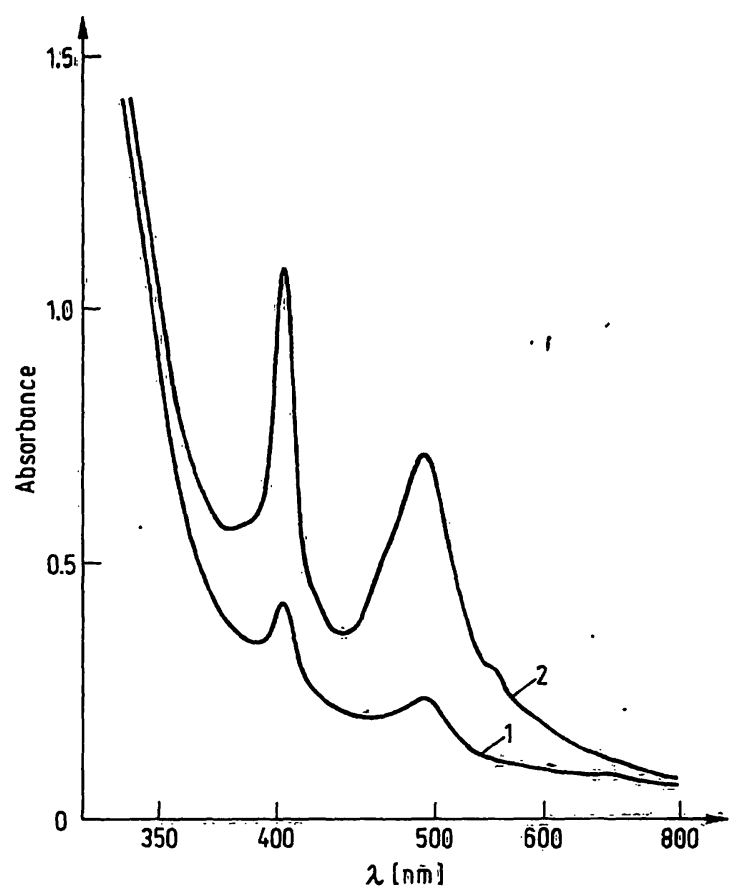

Fig. 1. Change of absorption spectra before (1) and after oxidation with Lugol solution (2). The rise in absorbance in Soret maximum (near $400 \mathrm{~nm}$ ) represents the change of concentration of porphyrins (1: $785 \mathrm{nmol} / 1$, $2: 3,564 \mathrm{nmol} / \mathrm{l})$. Urine of patient with acute intermittent porphyria).

\section{Results and Discussion}

Differences in the content of porphyrinogens from patients with porphyria cutanea tarda and patients with acute intermittent porphyria were investigated (fig. 1 , fig. 2).

The levels of porphyrins before oxidation in acute intermittent porphyria were in the range $92 \mathrm{nmol} / \mathrm{l}$ to $918 \mathrm{nmol} / \mathrm{l}$, and after oxidation the range was $386 \mathrm{nmol} / \mathrm{l}$ to $6,429 \mathrm{nmol} / 1$. The content of porphyrinogens was on

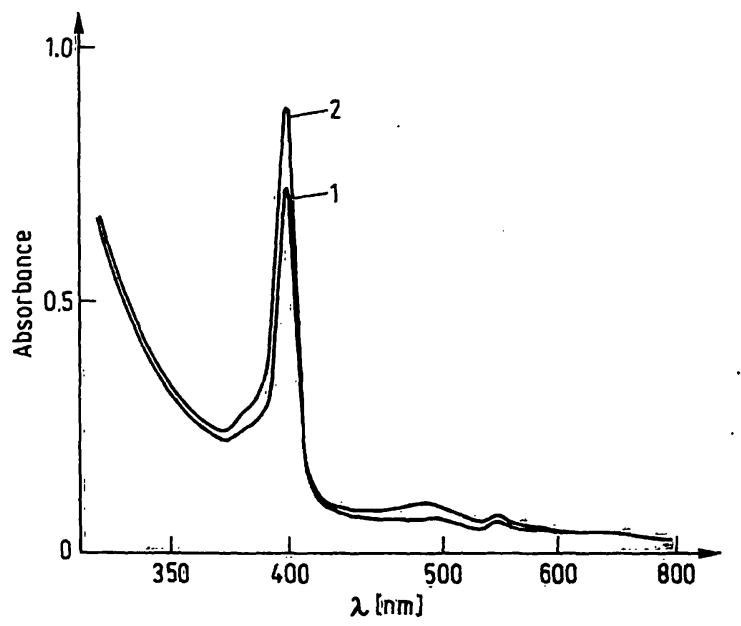

Fig. 2. Initial (before oxidation, $1: 6,740 \mathrm{nmol} / \mathrm{l}$ ) and total (after oxidation with Lugol solution, 2: 8,235 nmol/1) porphyrin concentrations. Urine of patient with porphyria cutanea tarda. 


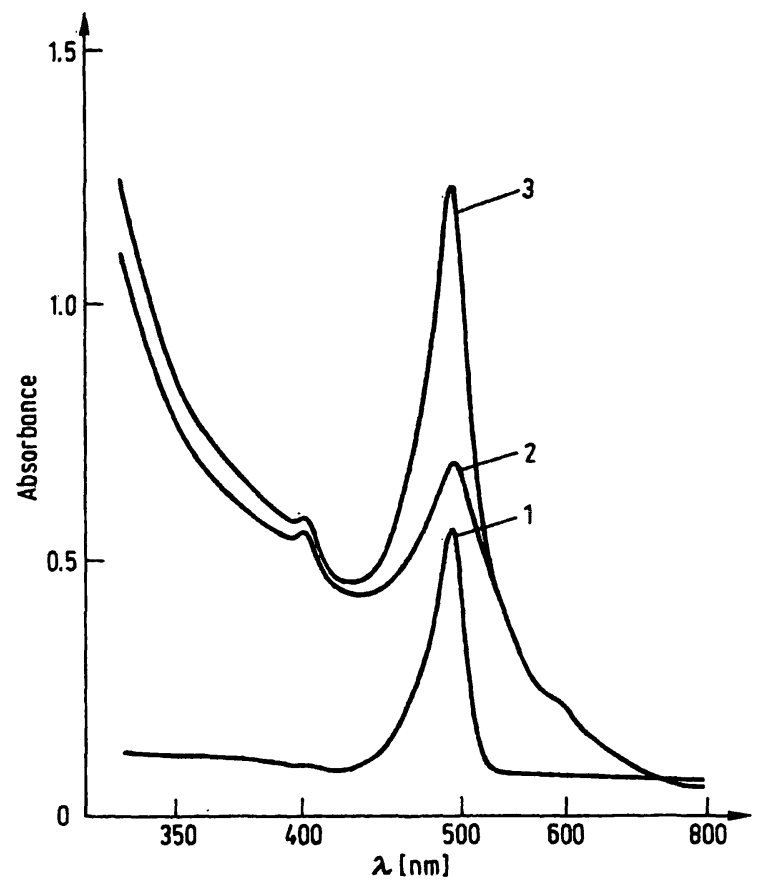

Fig. 3. 1: $80 \mathrm{nmol} / \mathrm{l}$ of pure stercobilin in $\mathrm{H}_{2} \mathrm{SO}_{4}(1 \mathrm{~mol} / \mathrm{l})$ 2: urine from non porphyric cirrhotic patient after oxidation with Lugol solution using the described method (To $1 \mathrm{ml}$ urine $8.75 \mathrm{ml}$ of $\mathrm{H}_{2} \mathrm{SO}_{4}-1 \mathrm{~mol} / 1$ and $0.25 \mathrm{ml}$ of Lugol solution was added and then a small crystal of cysteine). 3: the same urine as described after addition of $96 \mathrm{nmol} / 1$ of stercobilin.

average $77.1 \%$ (SD 9.3\%) of total porphyrins. The finding of a second peak with a maximum $483-484 \mathrm{~nm}$ was usual after oxidation in this group (fig. 1). Dipyrrylmethenes (absorption maximum $483 \mathrm{~nm}$ ) and urobilinoids ( $495 \mathrm{~nm}$, fig. 3 ) absorb close to one another in this area (19).

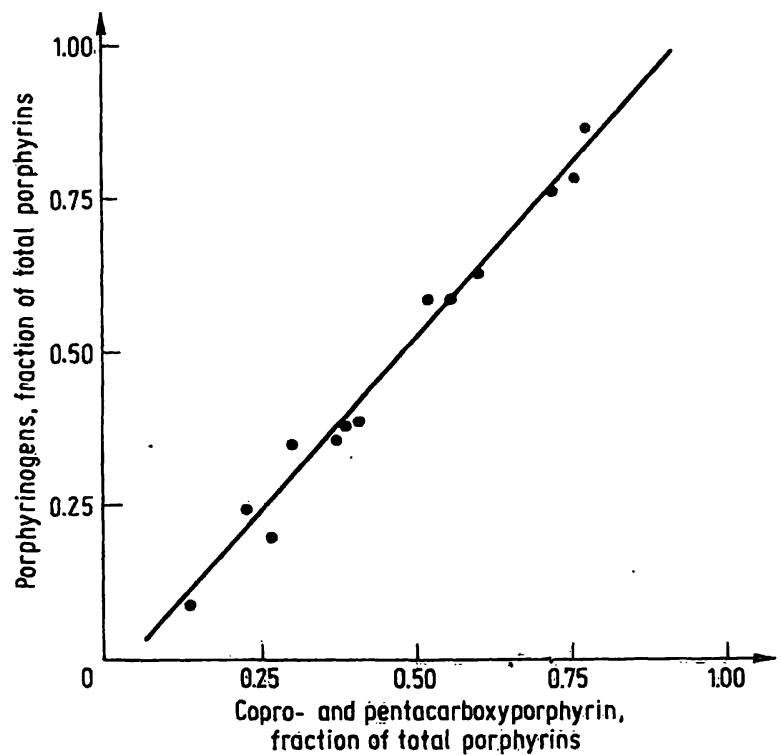

Fig. 4. Correlation of percentual content of porphyrinogens determined spectrophotometrically by described method and the sum of copro-and pentacarboxyporphyrins in relation to total porphyrins in thin-layer chromatography in corresponding samples of urine. Urine of patients with acute intermittent porphyria and porphyria cutanea tarda.

$(y=1.14 x-4.61 ; x=0.986 ; n=13)$.
The levels of porphyrins before oxidation in porphyria cutanea tarda were from 1,028 to $11,062 \mathrm{nmol} / 1$. After oxidation the range was 1,579 to $13,819 \mathrm{nmol} / 1$. The average content of porphyrinogens was $22.5 \%$ (SD $10.3 \%$ ) of total porphyrins. A separate paper will be dedicated to the excretion of porphyrinogens in different types of porphyrias.

A correlation is observed between the content of coproporphyrin, together with pentacarboxyporphyrin, and the percentual content of porphyrinogens in simultaneous densitometric and photometric determinations. From the presented correlations, it is evident that coproporphyrin and pentacarboxyporphyrin are excreted mostly like porphyrinogens (fig. 4). Similar correlations were found, even with the method of adsorption on talc. We showed that porphyrinogens are not adsorbed on talc and remain in the filtrate, where it is possible to show their presence after their oxidation into porphyrins. We identified these porphyrins as copro- and pentacarboxyporphyrins by thin-layer chromatography (fig. 5 , fig. 6).

From the presented information it is evident that uroand heptacarboxyporphyrins are excreted in the oxidized form. In very fresh urine, which we studied, the oxidation of uro- and heptacarboxyporphyrins must have

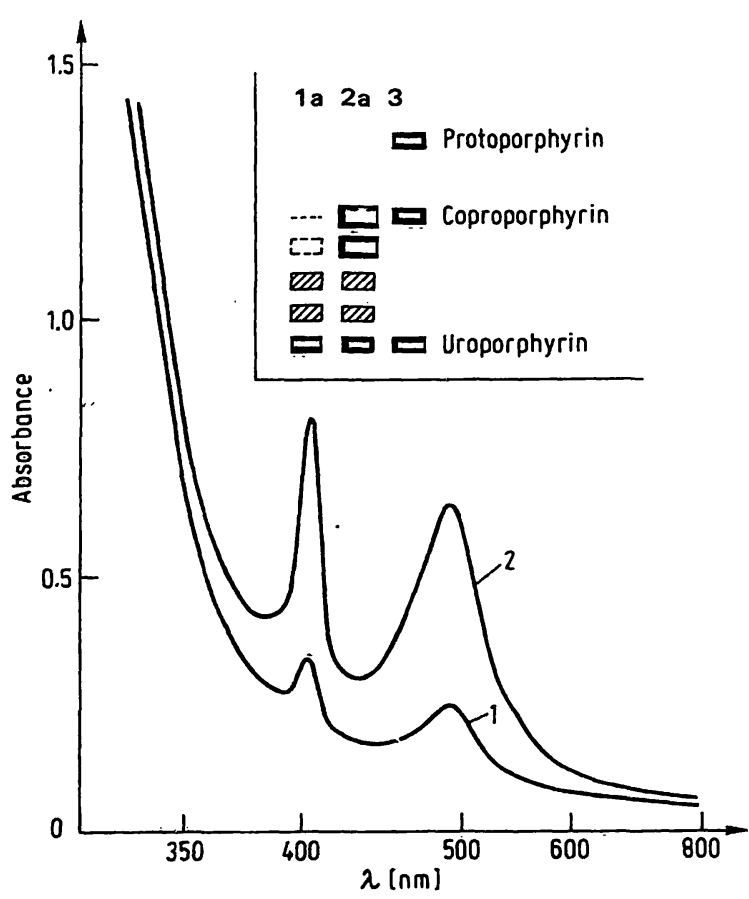

Fig. 5. Very fresh urine from acute intermittent porphyria patient:

1: spectral absorption of urine before talc extraction

1a: thin-layer chromatogram of porphyrins from talc adsorbate

2: spectral absorption of the same urine before talc extraction after oxidation with Lugol solution

2a: thin-layer chromatogram of porphyrins from talc adsorbate of urine after oxidation

3: thin-layer chromatogram of reference sample of porphyrins. 


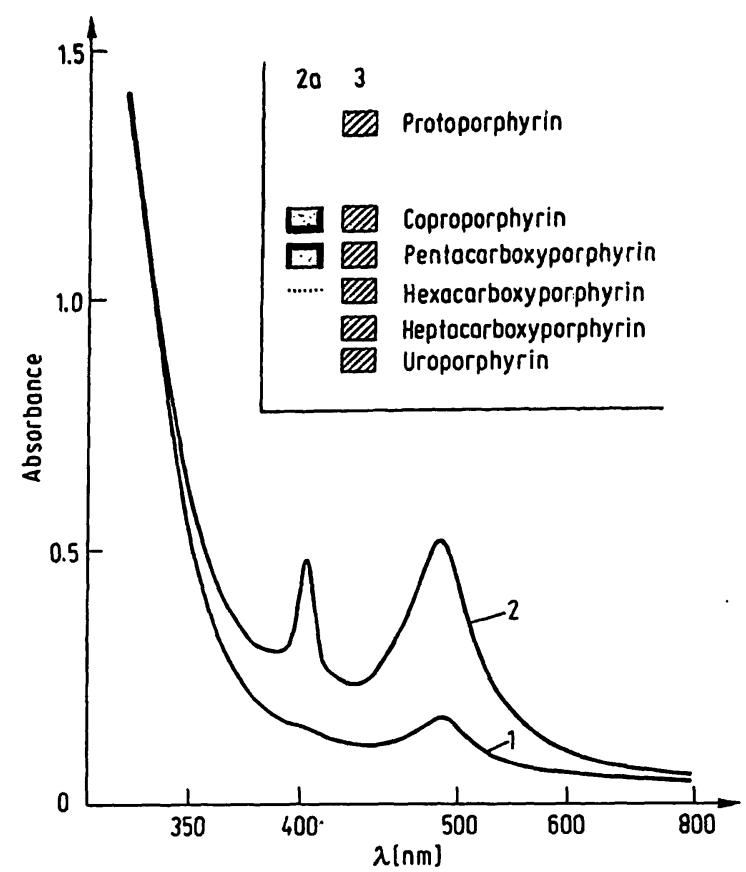

Fig. 6. Very fresh urine from acute intermittent porphyria patient:

Urine was adsorbed on talc before oxidation (porphyrins excreted in oxidized form were adsorbed on talc) and the filtrate was studied:

1: filtrate diluted with $\mathrm{H}_{2} \mathrm{SO}_{4}$ without oxidation with Lugol solution

2: filtrate diluted with $\mathrm{H}_{2} \mathrm{SO}_{4}$ after oxidation with Lugol solution

2a: thin-layer chromatogram of porphyrins present in filtrate after oxidation

3: thin-layer chromatogram of reference sample of porphyrins.

occurred in the organism before the excretion of urine from the bladder. According to Rimington (20) "the porphyrins, once formed, do not appear to be reducible in vivo, and, therefore, become external to the metabolic stream". In vivo oxidation of uroporphyrinogen III to biosynthetically inactive porphyrin may be the basic defect in porphyria cutanea tarda (12). The mechanism and the exact place of oxidation is not clear. It would mean that uro- and heptacarboxyporphyrinogens are oxidized more easily in the body that copro- and pentacarboxyporphyrinogens, or that there is a different mechanism of oxidation. Our observation of oxidized porphyrins (uro- and heptacarboxyporphyrine type) in plasma and liver tissue in porphyria cutanea tarda patients is also in accordance with the above mentioned opinions.

It is essential to oxidize with Lugol solution before determination of porphyrins according to With (7), especially in acute intermittent porphyria. Acidification by itself is insufficient because oxidation in an acidic medium occurs slowly and incompletely (fig. 7). The spontaneous oxidation in standing urine takes hours and is dependent on a number of different conditions $(\mathrm{pH}$, light, other components in urine). Because porphyrino-

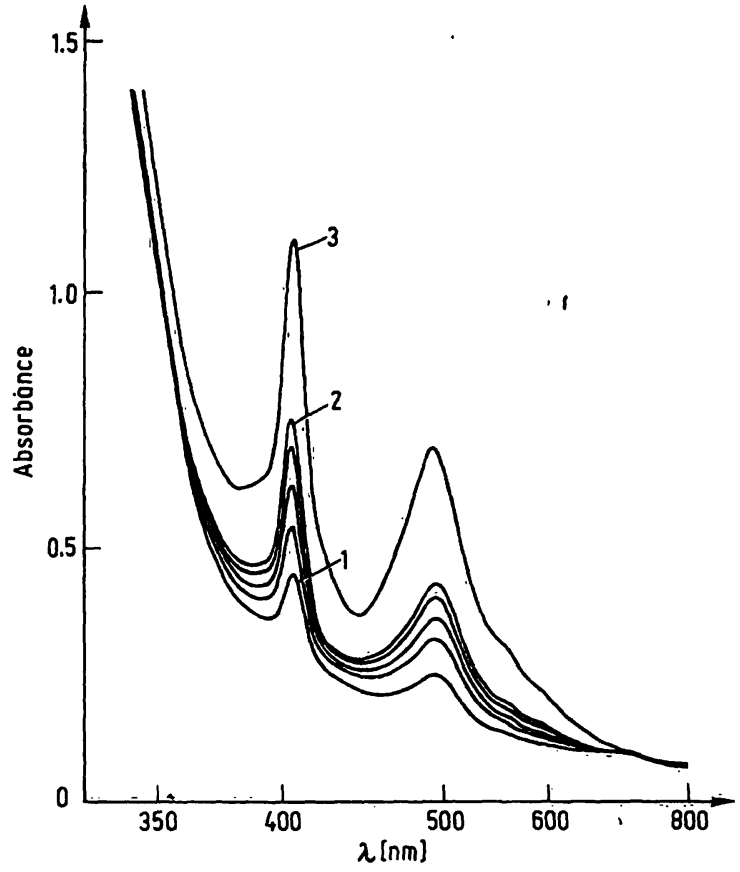

Fig. 7. Spontaneous oxidation of porphyrinogens in $\mathrm{HCl}$ (1 $\mathrm{mol} / \mathrm{l}$ ) (Further increase in $\mathrm{HCl}$ concentration causes a gradual decomposition of porphyrinogens):

1: initial curve (porphyrin content $-785 \mathrm{nmol} / \mathrm{l}$ )

1-2: spontaneous oxidation of porphyrinogens measured at $\mathbf{3 0} \mathrm{min}$ intervals (diluted urine was standing in the recording spectrophotometer)

2: $\quad$ spontaneous oxidation after $120 \min (2,105 \mathrm{nmol} / 1)$

3: immediate oxidation with Lugol solution $(3,563 \mathrm{nmol} / \mathrm{l})$

Urine of patient with acute intermittent porphyria.

gens are not adsorbed on talc, methods which use adsorption on talc in acute intermittent porphyria as the first step, can give inaccurate results. The losses of copro: and pentacarboxyporphyrins can sometimes be as high as $30-40 \%$. We therefore recommend in this case oxidation with Lugol solution before adsorption on talc.

Tab. 1. Comparison of two oxidants on yield of porphyrins from corresponding porphyrinogens. Pure coproporphyrin (uroporphyrin*) was reduced according to Falk (16) to porphyrinogen and then oxidized by Lugol solution and chloranil.

\begin{tabular}{lll}
\hline & \multicolumn{2}{l}{ Porphyrins (nmol/1) } \\
\cline { 2 - 2 } No. & $\begin{array}{l}\text { Porphyrinogen } \\
\text { oxidized } \\
\text { by Lugol solution } \\
\text { (described method) }\end{array}$ & $\begin{array}{l}\text { Porphyrinogen } \\
\text { oxidized by chloranil } \\
\text { according to Schwartz (12) }\end{array}$ \\
\hline $1^{*}$ & 4,627 & 4,770 \\
$2^{*}$ & 1,386 & 1,406 \\
$3^{*}$ & 794 & 846 \\
4 & 8,004 & 7,155 \\
$5^{*}$ & 3,533 & 3,363 \\
6 & 1,682 & 1,773 \\
7 & 1,009 & 994 \\
\hline
\end{tabular}


We consider the analysis of very fresh urine to be important. The porphyrin content of samples taken at the same time of day can perhaps be helpful for the detailed analysis of different types of porphyria.

\section{References}

1. Elder, G. H., (1977) Sem. Hemat. 14, 227-242.

2. Fischer, H. \& Orth. H. (1937) in Die Chemie des Pyrrols, Bd. II, pp. 472-8, Akad. Verlagsgesellschaft, Leipzig.

3. Watson, C. J., Pimenta de Mello, R., Schwartz, S., Hawkinson, B. S. \& Bossenmaier, I. (1951) J. Lab. Clin. Med. 37, 831-842.

4. Holeček, V. (1957) Pracov. Lék. 9, 513-528.

5. Sano, S. \& Rimington, C. (1963) Biochem. J. 86, 203-212.

6. Eriksen, L. (1951) Scand. J. Clin. Lab. Invest. 3, 135-139.

7. With, T. K. \& Pedersen, J. S. (1978) Scand. J. Clin. Lab. Invest. 38, 279-289.

8. Eriksen, L. \& Eriksen, N. (1977) Scand. J. Clin. Lab. Invest. $37,357-361$.

9. Schwartz, S., Zieve, L. \& Watson, C. J. (1951) J. Lab. Clin. Med. 37, 843-859.

10. Jones, K. G. \& Sweeney, G. D. (1976) Biochem. Med. 15, 223-232.

\section{Acknowledgments}

We are indebted to Dr. Marcel Josifko (Statistical Center, Institute of Hygiene and Epidemiology) for invaluable help in calculating the statistical results.

11. Jones, K. G. \& Sweeney, G. D. (1979) Clin. Chem. 25, 71 74.

12. Schwartz, S., Edmondson, P., Stephenson, B., Sarkar, D. \& Freyholtz, H. (1976) Ann. Clin. Res. 8, 156-161.

13. Schwartz, S., Stephenson, B. \& Sarkar, D. (1976) Clin. Chem. 22, 1057-1061.

14. Kalivas, J. (1969) Clin. Biochem. 2, 417-421.

15. With, T. K. (1969) Dan. Med. Bull. 16, 267-280.

16. Falk, J. E. (1964) in Porphyrins and Metalloporphyrins, pp. 161-164, Elsevier, North-Holland Biomedical Press, Amsterdam.

17. Gray, C. H. (1953) in The Bile Pigments. pp. 124-126, Methuen, London.

18. Doss, M. (1971) Z. Klin. Chem. 8, 197-207.

19. Sears, W. G. \& Eales, L. (1974) Enzyme 17, 11-16.

20. Rimington, C. (1963) Ann. N.Y. Acad. Sci. 104, 666-675.

Dr. P. Martásek

1. interní klinika FVL UK,

$\mathrm{U}$ nemocnice 2

ČS-12802 Praha 
